\title{
Submerged microfiltration coupled with physcio-chemical processes as pretreatment to sea water desalination
}

\author{
R. Zhang, C. Khorshed, S. Vigneswaran*, J. Kandasamy \\ Faculty of Engineering, University of Technology, Sydney, P.O. Box 123, Broadway, NSW 2007, Australia \\ Tel.+61295142641; Fax.+61295142633; email: s.vigneswaran@uts.edu.au
}

Received 23 April 2009; Accepted 31 August 2009

\begin{abstract}
A B S T R ACT
In this study, the critical flux of the submerged membrane system was experimentally evaluated when it was used for seawater with and without pre-treatment. In this study, different processes such as flocculation with ferric chloride $\left(\mathrm{FeCl}_{3}\right)$ and different doses of PAC adsorption were used as a pre-treatment. The pretreatment of flocculant of $2 \mathrm{mg} / \mathrm{L}$ of $\mathrm{FeCl}_{3}$ and adsorption with the dose of $1 \mathrm{~g} / \mathrm{L}$ PAC showed an improvement in the critical flux from $5 \mathrm{~L} / \mathrm{m}^{2} . \mathrm{h}$ to $6.7 \mathrm{~L} / \mathrm{m}^{2} . \mathrm{h}$ and $13.3 \mathrm{~L} / \mathrm{m}^{2}$.h respectively. The performance of these pretreatments was also determined in terms of modified fouling index using ultrafilter membrane (UF-MFI). UF-MFI and SDI indicated that PAC adsorption was a better pretreatment than flocculation for the seawater used in this study. Molecular weight distribution (MWD) of seawater organic matter was also examined after different pretreatments. MWD of the raw seawater was mainly in the range from 1510 to $130 \mathrm{Da}$. It is observed that $\mathrm{FeCl}_{3}$ flocculation and $\mathrm{PAC}$ adsorption as pretreatments partially removed the organic matter of $1510 \mathrm{Da}$ and 130Da respectively.
\end{abstract}

Keywords: Critical flux; Adsorption; Preflocculation; Pretreatment; Seawater

\section{Introduction}

Effective pretreatment is the key for the sustainable operation of reverse osmosis (RO) used in desalination plants. Conventional pretreatment systems cannot reliably remove some pollutants which cause membrane fouling. Membrane processes, such as microfiltration (MF) and ultrafiltration (UF), are excellent techniques for the removal of suspended solids and colloids and for lowering RO fouling. Energy consumption in MF is relatively low and is even less than that of conventional pretreatment [1,2]. MF generally provides good quality feedwater for RO, with slightly lower COD/BOD, and silt density index (SDI) in comparison to the untreated seawater. However, the use of MF without other processes led to fouling and unsustainable operation. Recent studies proved that hybrid membrane processes (coupling

*Corresponding author. flocculation and/or adsorption with membranes) are efficient in simultaneously reducing membrane fouling and improving water quality [3,4]. However, such results are not available for sea and brackish waters and are of paramount importance for the rational design of pretreatment.

Low-pressure immersed (submerged) MF are energy efficient and are presently used successfully from smallscale $(0.1 \mathrm{~mL} / \mathrm{d})$ to large-scale $(375 \mathrm{~mL} / \mathrm{d})$ installations. Immersed membranes, although cost-effective, cannot alone remove dissolved organic matter effectively. Thus, there is a need to establish an integrated hybrid system incorporating immersed membranes with adsorption and flocculation. A long-term study with immersed membrane/adsorption hybrid system showed a consistent and superior organic removal with practically no membrane fouling [4].

One of the ways of reducing the fouling and limiting operation costs of MF is operating the MF below the critical flux. The operation of microfiltration below the 
critical flux (sustainable flux) reduces the microfiltration fouling. However, due to the presence of colloids and soluble organics in the seawater, the critical flux is quite low and non-sustainable. The critical flux of microfiltration can be increased by modifying hydrodynamic conditions (e.g. high-shear stress), but this results in higher energy consumption and higher operation cost. Pretreatment prior to the application of microfiltration can increase the critical flux. The influence of additives for modifying the colloidal fraction (flocculants) or entrapping the organic solutes (adsorbents) has to be evaluated, despite the increase in the operating cost due to these chemical/additives.

Therefore, an appropriate pretreatment is necessary to improve the performance of the submerged membrane system. The pretreatment can reduce the loading of dissolved organic matter (DOM) on membrane. Flocculation is one of the pretreatment methods that can improve the permeate flux and remove particles and colloids by membrane. The flocculation is used to achieve three objectives: eliminating the penetration of colloidal particles into the membrane pores, increasing the critical flux and modifying the characteristics of the deposit [5]. Adsorption is another pretreatment method which can remove dissolved organics, thereby reducing the membrane fouling.

The objectives of the study was to evaluate the pretreatments of flocculation and adsorption in terms of the (i) critical (sustainable) flux improvement in the submerged membrane system (ii) fouling potential (fouling index) reduction and (iii) fraction (molecular weight) of organic matter removed.

\section{Materials and methods}

\subsection{Seawater}

In this study, seawater was collected from Chowder Bay, Sydney. During the experiments the characteristics of seawater was monitored regularly. The seawater characteristics during the study period are presented in Table 1.

\subsection{Experimental}

In this study we used a submerged membrane system as a pretreatment process to seawater desalination with and without preflocculation and preadsorption. The schematic diagram of the submerged membrane system is shown in Fig. 1. Hollow fibre membrane module was used and its characteristics are summarized in Table 2. Seawater was pumped into the submerged membrane reactor using a feeding pump and the effluent (permeate) was collected at a predetermined flux using a suction pump. A pressure gauge was used to measure the transmembrane pressure (TMP) and a soaker hose air diffuser was used to provide air for membrane scouring.

Adsorption and flocculation pretreatment were performed using a lab-scale batch reactor equipped with mechanical stirrers. Powdered activated carbon (PAC, wood based) (Table 3) was used as adsorbent and ferric chloride $\left(\mathrm{FeCl}_{3}\right)$ was used for flocculant. After the adsorption and flocculation pretreatment, the treated seawater was settled down before passing it through submerged membrane system.

Table 1

Characteristics of seawater used in this study.

\begin{tabular}{|c|c|c|c|}
\hline Analysis category & Concentration & Analysis category & Concentration \\
\hline $\mathrm{pH}$ & 8.2 & $\mathrm{NO}_{2}-\mathrm{N}(\mathrm{mg} / \mathrm{L})$ & $<0.01$ \\
\hline Salinity $(\mathrm{g} / \mathrm{L})$ & $37-40$ & Se $(\mu \mathrm{g} / \mathrm{L})$ & $<25$ \\
\hline Conductivity $(\mathrm{ms} / \mathrm{cm})$ & $51.8-55.5$ & $\mathrm{Cr}(\mu \mathrm{g} / \mathrm{L})$ & $<25$ \\
\hline $\mathrm{TSS}^{*}(\mathrm{mg} / \mathrm{L})$ & $2-13$ & $\mathrm{Fe}(\mathrm{mg} / \mathrm{L})$ & $<0.05$ \\
\hline Turbidity (NTU) & $0.5-0.7$ & $\operatorname{Mn}(\mu \mathrm{g} / \mathrm{L})$ & $2-3$ \\
\hline Alkalinity $\left(\mathrm{mg} / \mathrm{L}\right.$ as $\left.\mathrm{CaCO}_{3}\right)$ & 66-80 (mostly bicarbonate) & $\mathrm{Ni}(\mu \mathrm{g} / \mathrm{L})$ & $<10$ \\
\hline $\mathrm{UV}_{254}$ & 0.026 & $\mathrm{Cu}(\mu \mathrm{g} / \mathrm{L})$ & $<10$ \\
\hline $\operatorname{DOC}^{* *}(\mathrm{mg} / \mathrm{L})$ & $<1$ & $\mathrm{~Pb}(\mu \mathrm{g} / \mathrm{L})$ & $<2$ \\
\hline $\mathrm{BOD}(\mathrm{mg} / \mathrm{L})$ & $<1$ & As $(\mu \mathrm{g} / \mathrm{L})$ & $<25$ \\
\hline Coliforms/100 mL & $<2$ & $\mathrm{Cd}(\mu \mathrm{g} / \mathrm{L})$ & $<0.1$ \\
\hline Total phosphorus (mg/L) & $<0.01-0.06$ & $\mathrm{Hg}(\mu \mathrm{g} / \mathrm{L})$ & $<1$ \\
\hline $\mathrm{NO}_{3}-\mathrm{N}(\mathrm{mg} / \mathrm{L})$ & 0.01 & $\mathrm{Zn}(\mathrm{mg} / \mathrm{L})$ & $<25$ \\
\hline $\mathrm{NH}_{4}^{3}-\mathrm{N}(\mathrm{mg} / \mathrm{L})$ & 0.02 & & \\
\hline
\end{tabular}

*Total suspended solids.

**Dissolved organic carbon. 


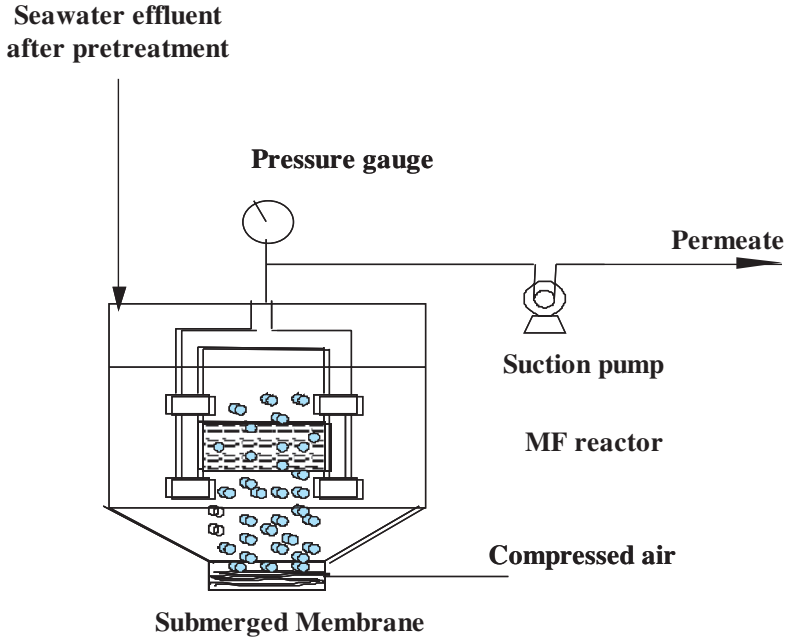

Fig. 1. Experimental set-up of submerged membrane system.

Table 2

Characteristics of the hollow fiber membrane module used.

\begin{tabular}{ll}
\hline Item & Characteristics \\
\hline Material & Hydrophilic polyethylene \\
Nominal pore size & $0.1 \mu \mathrm{m}$ \\
Outer diameter & $0.41 \mathrm{~mm}$ \\
Inner diameter & $0.27 \mathrm{~mm}$ \\
No. of fibre & $320(16 \times 20)$ \\
Length of fibre & $12 \mathrm{~cm}$ \\
Surface area & $0.05 \mathrm{~m}^{2}$ \\
Membrane packing density & $9858 \mathrm{~m}^{2} / \mathrm{m}^{3}$ \\
Membrane manufacturer & Mitsubishi-Rayon, Tokyo, \\
& Japan \\
\hline
\end{tabular}

Table 3

Characteristics of powdered activated carbon (PAC) used.

\begin{tabular}{ll}
\hline Specification & PAC-WB \\
\hline Iodine number $(\mathrm{mg} / \mathrm{g}$ min) & 900 \\
Ash content $(\%)$ & 6 max. \\
Moisture content $(\%)$ & 5 max. \\
Bulk density $\left(\mathrm{kg} / \mathrm{m}^{3}\right)$ & $290-390$ \\
Surface area $\left(\mathrm{m}^{2} / \mathrm{g}\right)$ & 882 \\
Nominal size & $80 \%$ min finer than 75 micron \\
Type & Wood based \\
Mean pore diameter $(\AA)$ & 30.61 \\
Micropore volumn $(\mathrm{cc} / \mathrm{g})$ & 0.34 \\
Mean diameter $(\mu \mathrm{m})$ & 19.71 \\
Product code & MD3545WB powder \\
\hline
\end{tabular}

\subsection{UF-MFI}

Modified Fouling index (MFI) by using ultrafilter membrane were measured after each pretreatment and the value of UP-MFI was calculated using following equation:

$$
\frac{t}{V}=\frac{\eta R_{m}}{\Delta P A}+\frac{\eta \alpha C_{b}}{2 \Delta P A^{2}} V
$$

Where,

$\mathrm{V}=$ total permeate volume (1)

$\mathrm{R}_{\mathrm{m}}=$ membrane resistance

$\mathrm{t}=$ filtration time $(\mathrm{s})$

$\Delta \mathrm{P}=$ applied trans-membrane pressure $(\mathrm{Pa})$

$\eta=$ water viscosity at $20^{\circ} \mathrm{C}\left(\mathrm{N} \mathrm{s} / \mathrm{m}^{2}\right)$

$\alpha=$ the specific resistance of the cake deposited

$\mathrm{C}_{\mathrm{b}}=$ the concentration of particles in a feed water $(\mathrm{mg} / \mathrm{L})$

$\mathrm{A}=$ the membrane surface area $\left(\mathrm{m}^{2}\right)$

MFI is defined as the gradient of this linear region of $\mathrm{t} / \mathrm{V}$ vs. $\mathrm{V}$ plot normalized to standard reference values of $207 \pm 3 \mathrm{kPa}$ transmembrane pressure, a feed water temperature of $20^{\circ} \mathrm{C}$ and MF with a surface area of $47 \mathrm{~mm}$ diameter and molecular cutt off is $30 \mathrm{kDa}$.

\subsection{Molecular weight distribution (MWD) of organic matter}

The seawater effluent after each pretreatment was subjected to MWD measurement to investigate seawater organic matter (SWOM) removal. High-pressure size exclusion chromatography (HPSEC, Shimadzu Corp., Japan) with a SEC column (Protein-pak 125, Waters Milford, USA) was used to determine the MW distributions of SWOM. Standards of MW of various polystyrene sulfonates (PSS: 210, 1800, 4600, 8000, and 18000 daltons) were used to calibrate the equipment. The weight-averaged molecular weight can be calculated from the following equation;

$$
M_{w}=\sum_{i=1}^{n}\left(N_{i} M_{i}^{2}\right) / \sum_{i=1}^{n}\left(N_{i} M_{i}\right)
$$

\section{Results and discussion}

\subsection{Critical flux experiments with seawater}

Critical flux is defined as the maximum flux at which the membrane system can operate without any accumulation of foulants on the membrane [6]. The flux step method is a common experimental technique for determining critical flux [7]. Flux is held constant for the specified filtration time ( 1 hour in this study) during which 

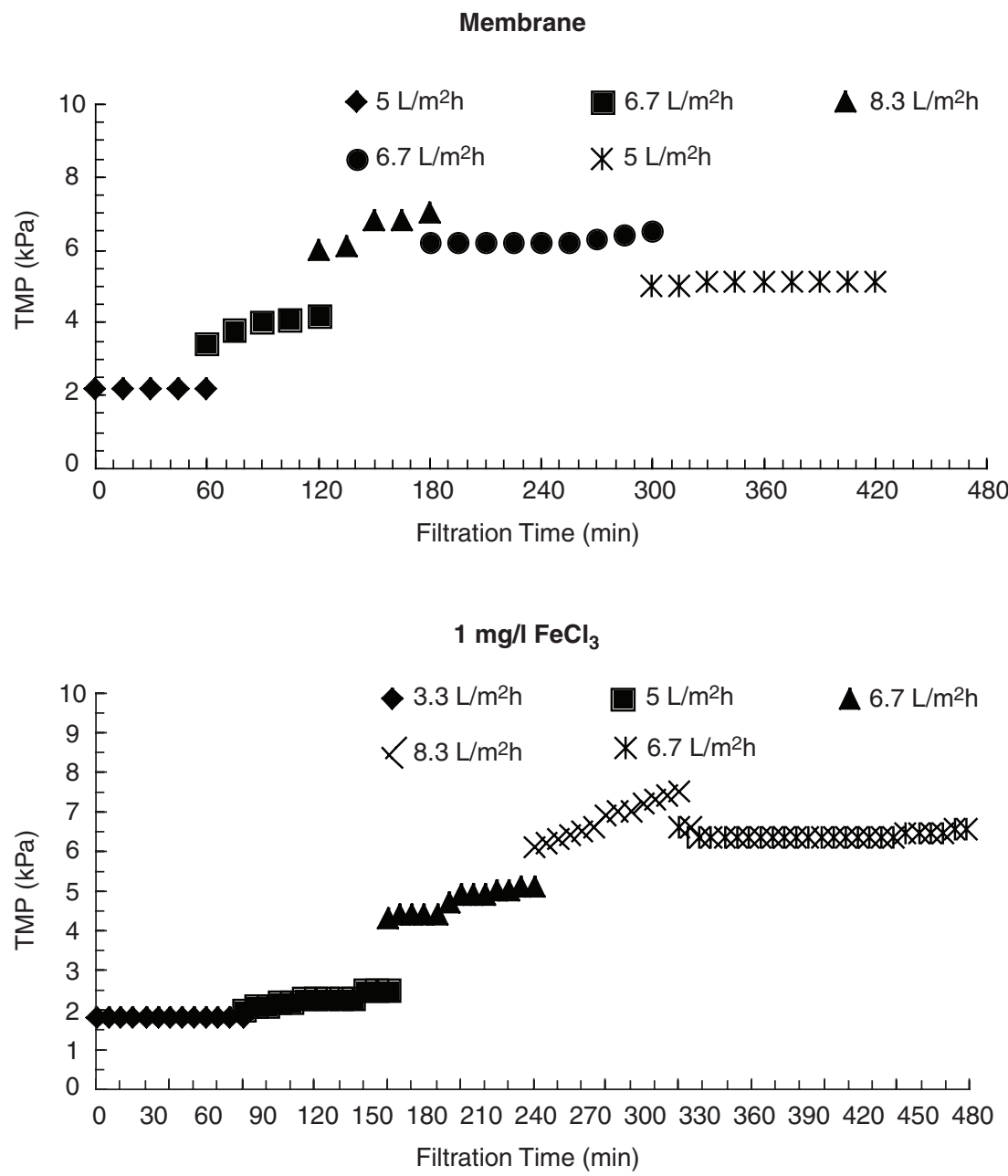

Fig. 2. Constant filtration flux experiments with seawater (with and without preflocculation) (membrane pore size $0.45 \mu \mathrm{m}$; $\mathrm{FeCl}_{3}$ dose = $1 \mathrm{mg} / \mathrm{L}$; air flowrate $5 \mathrm{~m}^{3} / \mathrm{m}^{2}$ membrane area/hr).

the evolution of trans-membrane pressure (TMP) is monitored with time. The critical flux is the lowest set-point flux at which the suction pressure is noted to increase with time due to fouling rather than remaining constant.

Figure 2 shows the variation of TMP value for constant filtration flux using the seawater without and with preflocculation. Flocculation was provided in batch mode in the following conditions: addition of $\mathrm{FeCl}_{3}(1 \mathrm{mg} / \mathrm{L})$, agitation during 20 minutes and settling for 20 minutes prior to application of the supernatant to submerged membrane system. The critical flux was around $5 \mathrm{~L} / \mathrm{m}^{2} . \mathrm{h}$ for the seawater without pre-flocculation (Fig. 2a). It increased to $6.7 \mathrm{~L} / \mathrm{m}^{2}$.h when a pretreatment of flocculation was provided (Fig. 2b). The pre-flocculation helped in capturing and agglomerating colloids, thereby reducing the membrane fouling by colloids. According to the results, flocculation had more considerable effect on the critical flux than adsorption.

The effect of adsorption as pretreatment on critical flux is shown in Fig. 3. Here two different doses of PAC
(0.05 and $1 \mathrm{~g} / \mathrm{L})$ were added in the seawater and mixed for 1 hour before the PAC was settled down for 1 hour. With the pretreatment of adsorption with $0.05 \mathrm{~g} / \mathrm{L} \mathrm{PAC}$, the critical flux increased from 5 to $6.7 \mathrm{~L} / \mathrm{m}^{2} . \mathrm{h}$. When a dose of $1 \mathrm{~g} / \mathrm{L}$ PAC was used the critical flux increased from 5 to $13.3 \mathrm{~L} / \mathrm{m}^{2} . \mathrm{h}$. The results indicated that the pretreatment of flocculation and adsorption was able to remove large and small molecular weight organic matter respectively while enhancing the filtration flux of submerged membrane system and dissolved organic removal.

\subsection{Molecular weight distribution (MWD) after different pretreatment}

The MWD of SWOM in seawater was measured after each pretreatment. The MW of the untreated seawater ranged from about 1510 to $130 \mathrm{Da}$. Typical MW peaks for the seawater was found at around $1510 \mathrm{Da}, 1180 \mathrm{Da}, 530$ and 130 Da (Fig. 4). 

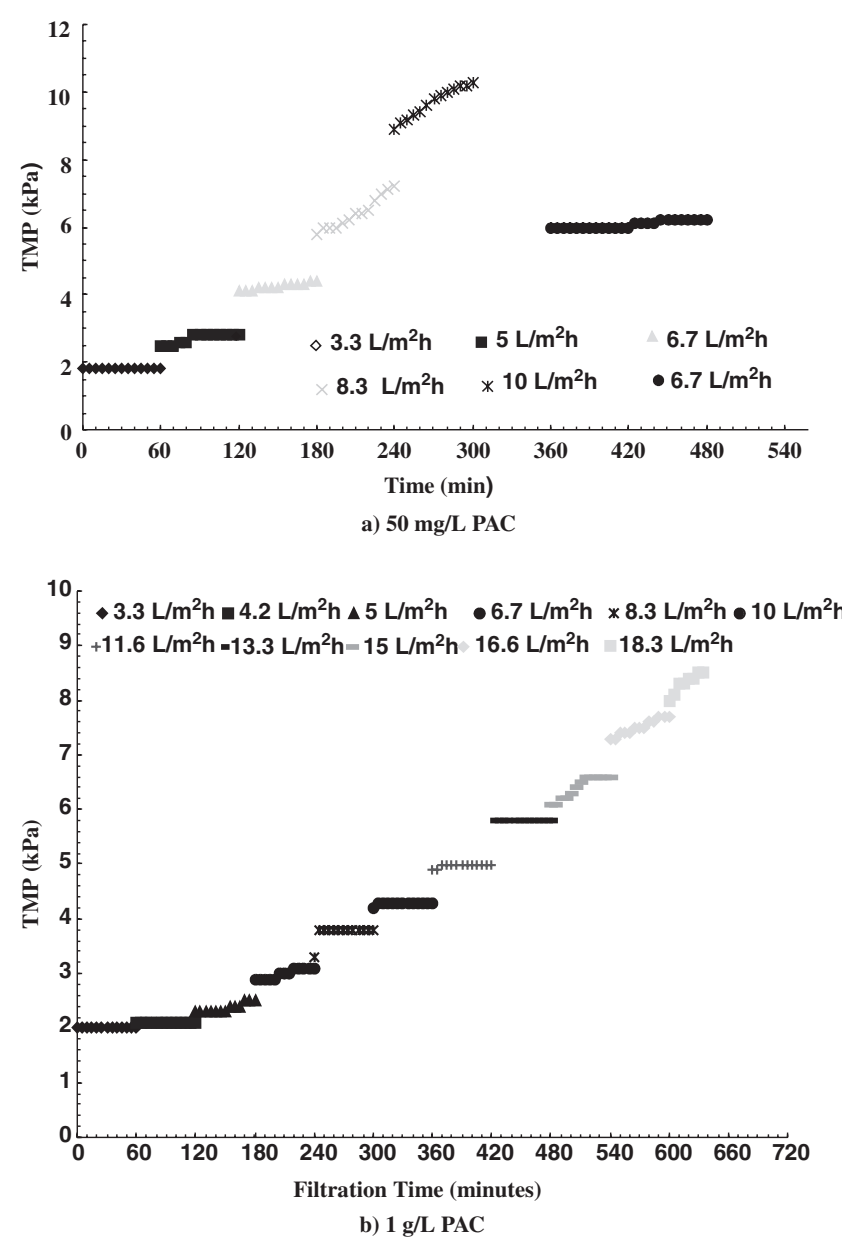

Fig. 3. Constant filtration flux with seawater after adsorption (membrane pore size $=0.45 \mu \mathrm{m}$; PAC dose $=2 \mathrm{~g} / \mathrm{L}$ ).

The organic matter corresponding with the MW fraction of $1510 \mathrm{Da}, 1180 \mathrm{Da}, 530$ and $130 \mathrm{Da}$ represents biopolymers (polysaccharides and proteins), fulvic acid, low MW acids (hydrolysates of humic substances), and amphiphilics, respectively [4,8]. Figure 4 shows the MWD of SWOM with and without prereatment. The microfiltration alone did not remove any organic matter and the MWD of microfiltration effluent was almost similar to that of seawater. The flocculation and adsorption as pretreatment to MF partially removed $1570 \mathrm{Da}$ and 530 Da respectively.

\subsection{Effect of pretreatment on fouling reduction}

The relative merits of different pretreatments were studied in terms of fouling potential. Modified fouling index using ultrafilter membrane of $30 \mathrm{kDa}$ (UF-MFI) and $\mathrm{SDI}_{15}$ (using 0.45 microfilter membrane) measurements were made to compare the different pretreatments. UF-MFI and $\mathrm{SDI}_{15}$ was measured using dead

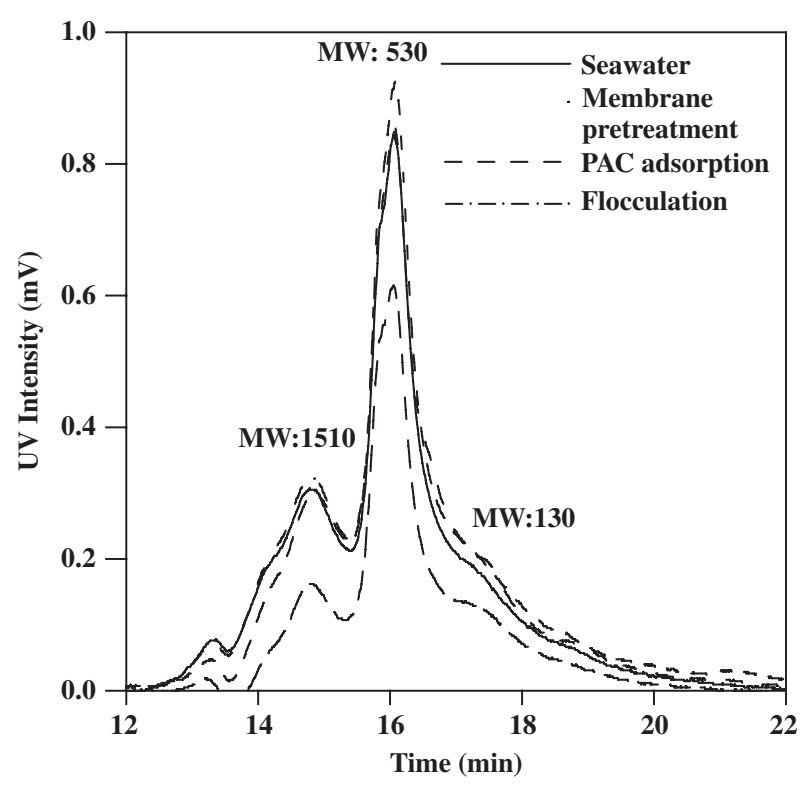

Fig. 4. MW distribution of SWOM (seawater organic matter) of seawater and with pretreated seawater.

end cell. The UF-MFI and $\mathrm{SDI}_{15}$ of raw seawater were $4531 \mathrm{~s} / \mathrm{L}^{2}$ and 5.8, respectively. After the pre-treatment of flocculation with $\mathrm{FeCl}_{3}$ (of $1 \mathrm{mg} / \mathrm{L}$ ), the UF-MFI was decreased to $2305 \mathrm{~s} / \mathrm{L}^{2}$ and 4.5 . This may be due to the formation of flocs of different sizes during flocculation which lead to reduce the fouling. On the other hand, a pretreatment with PAC adsorption with $0.05 \mathrm{~g} / \mathrm{L}$ gave rise to higher organic removal and also resulted in a very low UF-MFI and SDI $_{15}$ value of $1329 \mathrm{~s} / \mathrm{L}^{2}$ and 3 respectively.

\section{Conclusion}

1. The pretreatment of PAC adsorption with a dose of $1 \mathrm{~g} / \mathrm{L}$ showed an improvement in the critical flux up to $13.3 \mathrm{~L} / \mathrm{m}^{2}$.h. The preflocculation could marginally increase the critical flux up to $6.7 \mathrm{~L} / \mathrm{m}^{2} . \mathrm{h}$ from $5 \mathrm{~L} / \mathrm{m}^{2} . \mathrm{h}$.

2. The performance of these pre-treatments was determined in terms of modified fouling index using ultrafilter membrane (UF-MFI) and silt density index (SDI). UF-MFI and SDI indicated that PAC adsorption was better pretreatment than flocculation. The UF-MFI and $\mathrm{SDI}_{15}$ of raw seawater were $4531 \mathrm{~s} / \mathrm{L}^{2}$ and 5.8 , respectively. After the pre-treatment of flocculation with $\mathrm{FeCl}_{3}$ (of $1 \mathrm{mg} / \mathrm{L}$ ), the UF-MFI was decreased to $2305 \mathrm{~s} / \mathrm{L}^{2}$ and 4.5. On the other hand, a pretreatment with PAC adsorption with $0.05 \mathrm{~g} / \mathrm{L}$ gave rise to higher organic removal and also resulted in a very low UF-MFI and $\mathrm{SDI}_{15}$ value of $1329 \mathrm{~s} / \mathrm{L}^{2}$ and 3 respectively. 
3. Detailed molecular weight distribution (MWD) of seawater organic matter was examined after different pretreatments. MWD of the initial seawater mainly ranged from 1510 to $130 \mathrm{Da}$. It is observed that $\mathrm{FeCl}_{3}$ flocculation and PAC adsorption as a pretreatment is partially removed the organic matter corresponding to $1510 \mathrm{Da}$ and $530 \mathrm{Da}$ respectively.

\section{References}

[1] B. Van der Bruggen and C. Vandecasteele, Desalination, 143 (2002) 207-218.
[2] S. Ebrahim, M. Abdel-Jawad, S. Bou-Hamad and M. Safar, Desalination, 135 (2001) 141-153.

[3] H.K. Shon, S. Vigneswaran, In S. Kim, J. Cho and H.H. Ngo, Water Research, 38 (2004) 1933-1939.

[4] W. S. Guo, H. Chapman, S. Vigneswaran and H.H. Ngo, Journal of Membrane Science, 242 (2004) 27-35.

[5] R. Ben Aim, M. Mietton-Peuchot, S. Vigneswaran, K. Yamamoto and S. Boonthanon, Proceeding of water pollution control IAWPRC, 1988, 613-619.

[6] R.W. Field, D. Wu, J.A. Howell and B.B. Gupta, Journal of Membrane Science, 100 (1995) 259-272.

[7] P. L. Clech, B. Jefferson, I.S. Chang and S.J. Judd, Journal of Membrane Science, 227 (2003) 81-93.

[8] S.A. Huber, Desalination, 119 (1998) 229-234. 